\title{
The Greek economy under the twin-deficit pressure: a demand orientated growth approach
}

\begin{abstract}
This paper uses an alternative growth approach in line with Thirlwall's model in order to predict economic growth in Greece taking into account internal and external imbalances caused by public deficit/debt and lack of trade competitiveness. It is shown that the simple Thirlwall's Law (given by the product of the ratio of the income elasticities of demand for exports and imports, and the growth of foreign demand) over-predicts real growth in Greece while the more complete extended model, makes a closer prediction which is consistent with the high deficit/debt and current account deficit experienced in this country. The simulation approach shows that the most efficient policy to attain higher growth is to reduce external imbalances while policies to reduce internal imbalances are low growth enhancing.
\end{abstract}

JEL code: $\mathrm{C} 32, \mathrm{H} 6, \mathrm{O} 4$

Keywords: internal and external imbalances, price and no price competitiveness, extended growth model, 3SLS system regressions, supply constraints. 


\section{Introduction}

The new growth theory - or endogenous growth theory- has its origin in the predictive failure of the neoclassical growth model as originally developed by Solow (1956). The endogenous growth approach replaced the diminishing returns to capital assumption with the increasing returns of human capital, and abandoned the exogenous technical progress supposition. In this respect, the endogenous growth theory becomes closer to the Keynesian paradigm that factor inputs are endogenous and determined by the demand strength (Romero and McCombie, 2014). Although the new growth theory recognizes the endogenous nature of output growth, it does not consider explicitly that growth can be balance-of-payments constrained.

The early Harrod-Kaldor tradition highlighted the balance-of-payments disequilibrium as the most important constraining factor for the growth of demand (Thirlwall, 1982; McCombie, 1985; Hussein and Thirlwall, 2000). In this strand of growth theory, Thirlwall (1979) argued that no country can grow faster than the rate consistent with the balance-of-payments equilibrium (on current account). The only exception occurs when a country finances external deficits through capital flows which in most cases cannot be a permanent solution. The balance of payments equilibrium growth rate is obtained by dividing the growth of real exports to the income elasticity of the demand for imports, and this simple relation became known as the Thirlwall's Law. Alternatively, the product of the ratio of the income elasticity of the demand for exports to that of imports, and the growth of foreign demand, defines the growth rate consistent with the balance of payments equilibrium, on current account. When countries do not respect this simple rule sooner or later they will face serious problems in financing the external debt, and in the absence of capital flows it will be necessary to contract demand and thus growth. According to this Law, growth is constrained by external demand and the capacity of a country to produce goods and services with high elasticity of demand in international 
markets. In case of external imbalances, it is income and not relative prices that adjusts to bring the economy back to equilibrium.

Several empirical studies have emerged, either testing the validity of Thirlwall's Law or criticizing its main assumptions, namely that relative prices are constant in the long-run and that current account is initially balanced ${ }^{1}$. Thirlwall and Hussain (1982) revised the initial model relaxing the condition of the balance-of-payments equilibrium and allowing for capital flows that could finance external trade imbalances. Among others, McCombie (1989), Moreno-Brid (1998-99), McCombie and Thirlwall (1994), and Blecker (2009) have made valuable contributions to the discussion of the underlying implications of Thirlwall's Law. Evidence in the empirical literature suggests that income is the variable that adjusts to equilibrate external imbalances, implying therefore that growth is indeed balance-of-payments constrained. On the other hand, increasing capital inflows can at most be only a temporary way of relaxing the balance-of-payments constraint.

Despite the modifications made on Thirlwall's model, few papers (Soukiazis et al., 2012; 2014; 2015) have considered the role of public imbalances - caused by public deficit and debt - as additional constraints to economic growth. The recent experience of Greece (and other peripheral UE countries) falling into a public-debt trap is our main motivation for dealing with this issue. How a budget deficit-recession cycle can be overwhelmed has many and different aspects from a macroeconomic perspective. The implementation of an expansionary fiscal policy is not always a successful policy for enhancing growth and reducing unemployment (Pelagisis and Desli, 2004). If deficits are financed by public borrowing implying higher public debt, higher interest rates for serving the debt, and crowd-out investment effects, all these will jeopardize the medium-term economic growth. On the other hand, Alesina and Perotti (1996) stated that fiscal adjustment relying on spending cuts on public transfers and on government

\footnotetext{
${ }^{1}$ On the history and new developments on Thirlwall's Law see Soukiazis and Cerqueira (2012).
} 
wage bill have better results than tax increases or cuts in public investment. Similarly, for the Greek economy, Hondroyiannis and Papaoikonomou (2014) estimated that the fiscal multiplier impact differs depending on the fiscal mix policy, the degree of openness, and the state of the economy. Moreover, aggressive austerity measures in order to keep public finances balanced may lead to a persistent vicious-cycle of low growth, high unemployment and needs for restructuring the debt as the case of Greece shows.

This paper aims at explaining why Greece had a different economic performance (lower growth and higher debt) than other European economies. The paper tries to shed light to this question through a theoretical, a descriptive and an empirical framework. More specifically, our goal is to identify particular characteristics of the Greek economy that could explain the current situation in Greece, falling in the debt-recession cycle. To do so an alternative growth approach is used which is an extension of Thirlwall's model. This augmented approach takes into consideration not only external (current account deficit) but also internal constraints emerging from fiscal deficits (the twin-deficit hypothesis). The model also relaxes the controversial assumption of the neutrality of relative prices, and uses the components of domestic income instead of its aggregate growth in the import function. Other specific determinants, such as, financial conditions for the payment of public debt, the share of foreign bond holders financing the debt, the tax rate on income, the import to export share and real exchange rate, as well as, important parameters extracted from the estimation approach are considered to explain domestic growth in Greece. The empirical framework estimates simultaneously the import, export, consumption and investment functions by $3 S L S$ in order to capture important interconnections between them and control for the endogeneity of regressors. Previously, this model has been applied to Portugal (Soukiazis-Cerqueira-Antunes, 2013), Italy (SoukiazisCerquera-Antunes 2014a), Slovakia (Soukiazis-Muchova-Cerqueira 2014b) and Romania (Soukiazis-Antunes-Stoian, 2015) ensuring a better prediction of actual growth in these 
countries $^{2}$. Although, there is a great number of surveys trying to explain the relationship between fiscal or monetary policy and economic growth in Greece, empirical evidence on external trade performance combined with internal imbalances is almost absent in the literature. Taking all these facts into consideration, the paper is organized as follows: Section 2 briefly explains the profile of the Greek economy in the last decades focusing on the twin-deficit performance. Section 3 tests the validity of Thirlwall's Law on the Greek economy and discusses its implications. Section 4 presents the extended growth model that takes into consideration internal and external constraints and relaxes the assumption of relative prices being neutral. Section 5 tests the extended model on the Greek economy trying to identify the main causes of its poor growth performance. Section 6 provides a scenario analysis focusing on the factors that could foster or harm economic growth in Greece. The last section of the study presents the main conclusions and discusses issues on policy implications that could help the country to farther improve its economic performance.

\section{The profile of the Greek economy}

Greece, after joining the EEC in 1981 and especially after being a member of the Eurozone in 2002, has shown some difficulties in adapting its shelf to the common European market, diverging from the cohesion group and the EU standards (Cardoso and Soukiazis, 2005). Currently, Greece faces severe economic problems due to an unsustainable debt that obliged the country to ask for external financial assistance. Under the Troika control (IMF, ECB and European Commission) since 2011, radical austerity measures were implemented affecting seriously the standards of living of the population without solving the debt problem. Loss of sovereignty, economic recession, unemployment, emigration and increased poverty were the consequences of the foreign intervention and the economic crisis took political and social

\footnotetext{
${ }^{2}$ Testing a model to different countries, different periods and different samples is the way to access its validity.
} 
dimensions. It is a fact that Greece is suffering the consequences of its political decisions in the last decades (Katsimi and Moutos, 2010; Mavroudeas, 2010).

Historically, Greece can be described as an economy with relatively high fiscal deficits (as a percentage of GDP) observing an average of $-7.6 \%$ in the period $1988-2014,-8.81 \%$ in the early period $1988-2000$ and $-6.47 \%$ in the later period $2001-2014$, as Figure 1 shows. The growth rates of GDP for the same periods are $0.95 \%, 1.6 \%$ and $0.02 \%$, respectively revealing that Greece grew at very low rates but faster in the pre- euro period (for more details see Table A in the Appendix A). Therefore, the anemic growth performance in Greece was followed by budget deficits that had to be financed by international borrowing aggravating public debt in the long term.

\section{Insert Figure 1}

As it can be seen in Figure 2, public debt is continuously rising and in 2014 reached $175.5 \%$ of GDP, being Greece on the top of the most indebted countries in the world. The indebtedness of Greece was higher in the euro period (125.84\%) facilitated by lower interest rates to pay external liabilities, in comparison to the pre-euro period (67.59\%), as Table A shows in Appendix A. However the debt ratio stayed stable from the early 1990s until the eruption of the crisis in 2010, showing afterwards an exponential increase.

\section{Insert Figure 2}

Apart from the internal imbalances (deficit/debt) Greece grew at the cost of accumulating also external imbalances. Figure 3 shows the current account (of the balance of payments) as percentage of GDP, observing a continuous deterioration especially in the euro period with the highest deficit reaching $-16.5 \%$ in 2008 . For the whole period $1981-2014$ the average rate of the current account deficit is -5.32 , while in the euro period is higher $-9.81 \%$ in comparison to the pre-euro period of $-2.19 \%$ (see Table A in Appendix A). All this shows that Greece lost its competitiveness with its accession to the strong currency group of the Eurozone. The 
implementation of the austerity measures after the debt crisis reduced drastically the current account deficit after 2010, due mostly to the decline in imports.

\section{Insert Figure 3}

We also report in Figure 4 historical data on growth rates for investment, consumption, exports and imports over the period 1981-2014. All variables show a positive trend before the eruption of the global financial crisis in 2008 with investment growing $2.85 \%$ on average, consumption $2.83 \%$, exports $5.5 \%$ and imports at a higher rate $6.62 \%$. As expected, after the financial crisis which coincides with the debt crisis in Greece there is a dramatic drop in all variables with investment falling on average $-13.28 \%$, consumption $-3.72 \%$, exports $-0.26 \%$ and imports $5.97 \%$.

\section{Insert Figure 4}

From the political perspective, consecutive Greek governments gained social peace and confidence of voters and consumers, through increasing public spending funded by continuous borrowing. This irresponsible policy led the Greek economy to a dramatic deterioration of the internal (deficit/debt) and external (current account) imbalances while capital inflows from the EU during the $80^{\prime}$ s and $90^{\prime} \mathrm{s}$ (in the form of structural funds) were used to promote consumption and the production of non-tradable goods (housing and infrastructures) rather than productive investment. This practice was facilitated by low interest rates when Greece became a member of the Eurozone in 2002. Low borrowing cost, credit facilities, excessive government spending and generous social policy gave to the population higher standards of living up to 2008, at the cost of accumulating public and external debt. When the international financial crisis came through in 2008, hit the most fragile peripheral economies of the EU, Greece being the first victim. The country entered in default in 2010 and asked for external financial aid. The main objectives of the agreement of the Greek governments with the European partners and the International Monetary Fund (IMF) were to reduce public deficits and turn public debt 
sustainable. However the results so far do not seem promising and the country still remains in the austerity vicious cycle without solving the debt problem.

Having all these developments into account, our aim is to use an alternative growth approach that takes into account the twin-deficit hypothesis to explain the responsibility of internal and external imbalances on the economic performance in Greece.

\section{The balance-of-payments constrained growth model}

Thirlwall (1979), in his seminar paper presented a simple model that determines the growth rate consistent with the balance-of-payments equilibrium. The basic premise of his model is that in the long-run, no country can grow faster than the rate consistent with its balance of payments equilibrium (on current account), unless it can finance ever-growing deficits by capital inflows which in practice it cannot. Financing external imbalances by borrowing cannot last forever involving the risk of default. A time will come where domestic income must slowdown ${ }^{3}$ in order to bring the economy back to equilibrium.

Thirlwall's model comprises the following relations, with all variables in growth rates:

$$
\begin{array}{lr}
\dot{p}_{d}+\dot{x}=\dot{p_{f}}+\dot{m} & \text { balance-of-payments identity } \\
\dot{m}=\psi\left(\dot{p_{f}}+\dot{e}-\dot{p_{d}}\right)+\pi \dot{y} & \text { demand for imports } \\
\dot{x}=h\left(\dot{p_{f}}+\dot{e}-\dot{p_{d}}\right)+\varepsilon \dot{y}^{*} & \text { demand for exports }
\end{array}
$$

where $\dot{x}$ and $\dot{m}$ are export and import growth rates, $\dot{p d}$ and $p \dot{f}$ are the growth of domestic and foreign prices, $\dot{e}$ is the change in exchange rate (the domestic price of foreign currency), $\dot{y}$ and $\dot{y}^{*}$ are the growth rates of domestic and foreign income, $\pi$ and $\varepsilon$ denote the income elasticities of the demand for imports and exports, and $\psi$ and $h$ the price elasticities of imports and exports, respectively.

\footnotetext{
${ }^{3}$ The income contraction may be the result of the austerity measures
} 
Substituting the import and export functions (2) and (3) into the external identity condition (1) and solving for domestic income we get the growth rate consistent with balance-of-payments equilibrium $\left(y_{B P}^{\cdot}\right)$ :

$$
\dot{y}_{B P}=\left[(1+\eta+\psi)\left(\dot{p}_{d}-\dot{p}_{f}-\dot{e}\right)+\varepsilon \dot{y}^{*}\right] / \pi
$$

Assuming that relative prices, expressed in a common currency, do not change over the longrun (the one price hypothesis), that is $(\dot{p d}-p \dot{f}-\dot{e})=0$, equation (4) reduces to:

$$
y_{B P}=\frac{\dot{x}}{\pi} \quad(5.1) \quad \text { or } \quad y_{B P}^{\dot{2}}=\frac{\varepsilon}{\pi} \dot{\mathrm{y}}^{*}
$$

The simple relation (5.1) is known as Thirlwall's Law indicating that the growth rate of domestic income consistent with the balance-of-payments equilibrium $\dot{y}_{B P}$ can be obtained dividing the growth of real exports $\dot{x}$ by the income elasticity of the demand for imports, $\pi$. The alternative expression (5.2) defines the growth rate of domestic income, given by the product of the growth of foreign income $\dot{y}^{*}$ and the ratio of the exports to imports income elasticities, $\varepsilon / \pi$. The ratio of the income elasticities captures the non-price competiveness of the economy associated with quality, design, innovation, variety, among other supply ${ }^{4}$ characteristics of the goods and services produced. Equation (5.2) has also a different interpretation stating that a country can grow faster than the rest of the world, that is $\dot{y}_{B P}>\dot{y}^{*}$ only when its income elasticity of the demand for exports exceeds its income elasticity of the demand for imports, $\varepsilon>\pi$. In other words, improving the non-price elasticity ratio is the only way to grow faster without harming external imbalances.

In order to test the validity of Thirlwall's Law it is necessary to estimate the import and export equations as defined in (2) and (3). The export and import equations can be estimated by OLS assuming that relative prices are exogenous since Greece is a small country and therefore is a

\footnotetext{
${ }^{4}$ Although Thirlwall's model is demand driven, it does not neglect the importance of the supply characteristics of the produced goods in international competition.
} 
price taker economy ${ }^{5}$. The average GDP growth rate of the OECD countries is used as foreign income since more than $80 \%$ of trade in Greece is made with this group of countries. The real effective exchange rate (annual changes) serves as proxy for relative prices. The regression results for both equations are shown in Table B.1 in Appendix B.

As it can be seen, only the income elasticities of the demand for imports and exports are statistically significant (at the $1 \%$ level). This is a common finding in the literature that imports and exports are income elastic and less sensitive to changes in relative prices ${ }^{6}$. Therefore, nonprice competitiveness is what matters in international trade reflecting the attractiveness of traded goods and services in terms of quality and other supply characteristics. Using the income elasticities of trade we are able to compute Thirlwall's Law as defined in (5.1) and (5.2), and the results are shown in Table 1.

It is shown that both versions of Thirlwall's model fail to make a close prediction of the actual growth in Greece. Both computed growth rates $(2.187 \%$ or $5.374 \%)$ overestimate the growth rate in Greece (consistent with the balance of payments equilibrium) in comparison to the actual average growth $(1.055 \%)$, especially the latter version that uses the income elasticity ratio. According to this result, the country grew at a much lower rate than the balance of payments equilibrium constraint allows, and should show current account surpluses. But this is not what really happened, since Greece has been accumulating external deficits over this period (at an average of $-8.44 \%$ of GDP). On the other hand, the income elasticity of exports $(4.616)^{7}$ being higher than that of imports (1.865) indicates that Greece should have grown faster than the OECD (2.17\%) countries, but this has not been the case.

\footnotetext{
${ }^{5} 3 S L S$ is also applied to estimate jointly the import and export equations but the results are similar to OLS.

${ }^{6}$ Although our results reveal that price elasticities are less important in international trade we should note that there are studies showing that the levels of relative prices (rather than changes) are more prevalent for growth especially for developing countries ((Rodrik, D., 2008; Rapetti,M., et al., 2012; Bógio, L., and Barbieri, L., 2016). ${ }^{7}$ This elasticity is unexpectedly high, knowing the lack of competitiveness of the Greek economy. Tourism can be the explanation since the exports we are using comprise also services and therefore revenues from tourism. To have an idea on this issue, international tourism receipts corresponded on average to $23.3 \%$ of total exports for the period 2005-2013 (World Development Indicators), and their contribution to Greek GDP was on average of 16.6\% for the period 2000-2013 (Bank of Greece).
} 


\section{Insert Table 1}

In the next section we will show that an extended model that takes into account also internal imbalances, among other financial factors, makes a closer prediction towards the actual growth observed in Greece.

\section{The extended growth model with internal and external constraints}

Recently, Soukiazis-Cerqueira-Antunes (2013) developed an alternative approach where domestic income partially depends on internal and external imbalances and it is sensitive to relative price fluctuations. In particular, this model is an extension to Thirlwall's model displaying three main differences: i) it considers not only external constraints (lack of competitiveness) but also internal ones, emerging from public deficit and debt, ii) instead of using aggregate domestic demand in the import function as in Thirlwall's model, uses the components of domestic income to measure their dependence on imports ${ }^{8}$, and iii) relative prices are introduced explicitly into the growth model. This alternative model can be described as follows, where variables with dot denote growth rates:

$$
\begin{array}{ll}
\dot{m}=\pi_{c} \dot{c}+\pi_{g} \dot{g}+\pi_{x} \dot{x}+\pi_{k} i \dot{n} v+\delta_{m}\left(\dot{p}^{*}+\dot{e}-\dot{p}\right) & \text { Imports } \\
\dot{x}=\varepsilon_{x} \dot{y}^{*}+\delta_{x}\left(\dot{p}^{*}+\dot{e}-\dot{p}\right) & \text { Exports }
\end{array}
$$

$$
\text { Private consumption (8) } i \dot{n} v=\varepsilon_{K} \dot{y}+\varepsilon_{r} \dot{r}
$$

Private investment

Equation (6) relates the growth of real imports $\dot{m}$ with the growth of the components of domestic income (consumption $\dot{c}$, government expenditures $\dot{g}$, exports $\dot{x}$ and private investment $\iota \dot{n v})$ and the growth of relative prices of imports given as $\left(p^{*} *+\dot{e}-\dot{p}\right)$ (where $p^{*} *$ is the growth of foreign prices, $\dot{e}$ the variation of nominal exchange rate ${ }^{9}$ and $\dot{p}$ the growth of

\footnotetext{
${ }^{8}$ Palley (2009-10) also suggests this decomposition of aggregate income in the import function.

${ }^{9}$ The domestic price of foreign currency
} 
domestic prices). The coefficients $\pi_{c}, \pi_{g}, \pi_{x}$ and $\pi_{k}$ are the import elasticities of the components of domestic income all expected with positive values since all components of demand have an import content. The relative price elasticity in the demand for imports $\delta_{m}$ is expected to be negative indicating that imports fall when they become more expensive in the domestic market, that is $\left(p^{*} *+\dot{e}\right)>\dot{p}$. Note that import prices can increase in domestic market through a depreciation of the domestic currency (an increase in $\dot{e}$ ).

Equation (7) defines the growth rate of real exports $\dot{x}$ to be determined by the growth of foreign income $y^{*} *$ and the growth of relative prices, defined in a similar way as in imports. Note that exports can increase as a result of domestic currency depreciation by turning exports more competitive in external markets, since $\dot{p}<\left(p^{*} *+\dot{e}\right)$. For this reason, the price elasticity of the demand for exports $\delta_{x}$ is expected to be positive. The coefficient $\varepsilon_{x}$ is the income elasticity of the demand for exports expected to be positive and its value captures the supply characteristics of the produced goods related to quality, design, product differentiation, etc.

Equation (8) is the standard consumption function, where the growth of real consumption $\dot{c}$ is basically explained by the growth of disposable income $\dot{y}_{\mathrm{d}}$ (including earnings from holding government bonds) and $\varepsilon_{c}$ is the income elasticity with respect to consumption. Finally, equation (9) is the private investment function that according to the accelerator theory, investment growth $\imath \dot{n} v$ is positively related with the growth of domestic income $\dot{y}$ and negatively related with real interest rate $\dot{r}$, since the latter represents the cost of financing additional investment. The coefficients $\varepsilon_{k}$ and $\varepsilon_{r}$ represent the income elasticity (accelerator effect) and interest rate elasticity with respect to investment growth.

Our extended model includes two farther relations (identities) which correspond to the internal and external balances of the economy. The government budget (variables in nominal terms) is given by:

$$
G_{n}+i B_{H}+i^{*} B_{F}=t Y P+D \quad \text { (budget identity) }
$$


where $G_{n}$ is nominal government expenditures, $B_{H}$ is public debt owned by home bond holders, $B_{F}$ is public debt owned by foreign bond holders, $Y$ is domestic income, $P$ is the domestic price level, $D$ stands for public deficit, $i$ and $i^{*}$ are nominal interest rates paid to home and foreign public debt holders, respectively, $e$ is the nominal exchange rate, and $t$ is the tax rate on nominal income. According to this expression, we are in the presence of a public deficit when total current expenditures (including interest payments on public debt) exceed the revenues obtained through taxes on domestic money income.

As it is shown in Soukiazis-Cerqueira-Antunes (2012), the long-term behavior of the real government expenditures growth, compatible with the constraint as expressed in relation (10), is given by:

$$
\dot{g}=\frac{t \dot{y}}{w_{G}}+(\dot{d}-\dot{p}) \frac{w_{D}}{w_{G}}-\left[\Delta i+i\left(\dot{b}_{H}-\dot{p}\right)\right] \frac{w_{B H}}{w_{G}}-\left[\left(e \Delta i^{*}+i^{*} \Delta e\right)+i^{*} e\left(\dot{b}_{F}-\dot{p}\right)\right] \frac{w_{B F}}{w_{G}}
$$

where $w_{D}=\frac{D}{Y P}$ is the budget deficit ratio, $w_{G}=\frac{G}{Y P}$ is the government expenditure ratio, $w_{B H}=$ $\frac{B_{H}}{P Y}$ and $w_{B F}=\frac{B_{F}}{P Y}$ are the shares of public debt owned by home and foreign bond holders (as a percentage of nominal income), respectively, $\dot{d}$ is the growth of budget deficit and $\dot{b}_{H}$ and $\dot{b}_{F}$ are the growth rates of the public debt owned by home and foreign bond holders, respectively. In turn, the external balance condition is given by the following relation:

$$
X P+D_{F} e-i^{*} B_{F} e=M P^{*} e \quad \text { (external identity) }
$$

The left hand side of the identity shows the money resources available to finance imports $M P^{*} e$, that is, the export revenues $X P$ plus the amount of public deficit financed by foreigners $D_{F} e$ minus the interest rate payments to foreign bond holders $i^{*} B_{F} e$. As it is shown in SoukiazisCerqueira-Antunes (2012) the balance-of-payments final relation can be expressed as:

$$
\dot{x}+\dot{p}+(1-\xi) \frac{w_{D}}{w_{X}}\left(\dot{p}+\dot{y}-i^{*}\right)-(1-\xi) \frac{w_{B}}{w_{X}} \Delta i^{*}=\frac{w_{M}}{w_{X}} \frac{P^{*} e}{P}\left(\dot{m}+\dot{p}^{*}+\dot{e}\right)
$$

where $\dot{x}, \dot{m}, \dot{p}, \dot{p}^{*}, \dot{y}$, and $\dot{e}$ are the growth rates of exports, imports, domestic prices, foreign prices, domestic income and nominal exchange rate, respectively. Additionally, 
$w_{D}, w_{B}, w_{M}$, and $w_{X}$ are the ratios of budget deficit, public debt, imports and exports on income, and $(1-\xi)$ represents the percentage of public deficit (or debt) financed by external markets. Plugging equation (11) into the import equation (6) and the resulting form, together with equations (7) to (9) into the relation (13), the reduced form of the growth rate of domestic income can be obtained ${ }^{10}$ as given in equation (14):

$\dot{y}_{\text {ext }}=\frac{A}{B}$ where

and

$$
\begin{aligned}
& B=\frac{w_{M}}{w_{X}}\left(\frac{P^{*} e}{P}\right)\left\{\pi_{c} \varepsilon_{c}+\pi_{k} \varepsilon_{k}+\pi_{g}\left(\frac{t}{w_{G}}+\frac{w_{D}}{w_{G}}-\frac{i \xi w_{B}}{w_{G}}-i * e(1-\xi) \frac{w_{B}}{w_{G}}\right)\right\}- \\
& -(1-\xi) \frac{w_{D}}{w_{X}}
\end{aligned}
$$

As it is shown, the nominator of this expression explains the impact on domestic growth of four main components: (i) the positive effects of foreign demand $y^{*} *$ and the income elasticity of the demand for exports $\varepsilon_{x}$; (ii) the effects of the level of relative prices and the growth of relative prices, including the price elasticities of exports $\delta_{x}$ and imports $\delta_{m}$; (iii) the effects of budget deficit $w_{D}$ and debt $w_{B}$ and financial conditions, such as, the interest rates paid to consolidate internal imbalances and the share of foreign bond holders $(1-\xi)$ financing public debt; and (iv) the effect of the volume of trade where the share of imports to exports $w_{M} / w_{X}$ is the most prevalent factor. The denominator B mostly captures the effect of the disaggregated income

\footnotetext{
${ }^{10}$ More details on this derivation are given in Soukiazis-Cerqueira-Antunes (2012). Due to space limitations and to avoid replications we do not present the full development of the extended model.
} 
elasticities $\left(\pi_{c}, \pi_{k}\right.$ and $\left.\pi_{g}\right)$ of the demand for imports on the growth of domestic income. The higher the values of these elasticites the lower the growth of domestic income.

\section{Testing the extended model to the Greek economy}

In order to determine the growth rate of the Greek economy as given in equation (14) the import, export, consumption and investment functions (6) to (9) must be estimated to compute all the elasticities involved in the structural model. Equations (6) to (9) cannot be estimated by OLS for two main reasons: first, the equations contain endogenous explanatory variables, and therefore OLS estimators are biased and inconsistent; second, estimating individually each equation and not jointly all equations as a system, the estimation approach does not take into account the cross-equation error correlation. 2SLS could be applied by using instrumental variables to solve the problem of the endogeneity of regressors, but this method is not efficient since it estimates separately each equation ignoring therefore important linkages across equations. The most efficient estimation approach is 3SLS which takes into account both issues, controlling the endogeneity of regressors ${ }^{11}$ by using valid instruments, and taking into account the cross-equation correlation by estimating jointly all equations as a system (full information method). 3SLS implements the Generalized Least Squares (GLS) estimation approach to the system of equations involving three steps. In the first stage the reduced form of the system is estimated, by regressing all dependent variables on all exogenous variables of the system (including lag variables). In the second stage the fitted values of the endogenous variables are used as instruments to generate 2SLS estimates of all the equations in the system. The residuals of each equation are used to estimate the cross-equation variances and covariances of the cross-

\footnotetext{
11 The growth of imports, consumption, investment, and exports are assumed to be endogenous as well as the growth of government expenditures, domestic disposable income, domestic product and real domestic interest rate. The choice of the endogenous variables has been done on the basis of the definition of the structural equations in the system and the reciprocal interrelation between the dependent variables and the regressors supported by economic theory and policy orientation. All other variables in the system are assumed exogenous, including some lagged variables, as it is explained in Tables D.1 and D.2. The selection of the exogenous variables and instruments is controlled by the diagnostic tests reported in Table D.2 (Sargan test) which confirm their validity.
} 
equation error terms. In the third stage GLS is applied to the whole system to obtain efficient estimates (see Pindyck, R. S. and Rubinfeld, D.L.,1991).

We, therefore, estimate the four equations jointly by 3SLS, as the most efficient method that controls for the endogeneity of regressors and the cross-equation error correlation. Annual data (growth rates) are used for the period $1995-2014^{12}$ to estimate the system of the four equations. The definition of the variables and the data sources are explained in Appendix C. The full regression results are given in Table D.1 in Appendix D, and additionally the 2SLS is presented in Table D.2 to check the robustness of the results. The Sargan statistic, is a test of overidentification to check the validity of the instruments used in the regressions and this hypothesis is confirmed in all cases. The Pagan-Hall heteroskedasticity test, shows that the hypothesis of homoskedasticity is never rejected. ${ }^{13}$ The Cumby-Huizinga test for autocorrelation confirms that errors are not first-order autocorrelated in all cases. The endogeneity of regressors is controlled by a set of instrumental variables. The growth of imports, consumption, investment, and exports, as well as, the growth of government expenditures, domestic disposable income, domestic product, real exchange rate and real domestic interest rate are all assumed to be endogenous. All other variables in the system are taken exogenous, including some lagged variables, as it is explained in Tables D.1 and D.2 (in Appendix D).

Focusing on the 3SLS estimation approach, the results in general terms are satisfactory. In the import equation, exports and investment growth are the most significant variables at the $1 \%$ level. With respect to exports, the evidence shows that, other things being constant, every 1 percentage point (p.p.) increase in exports is associated with a 0.712 p.p. increase in imports.

\footnotetext{
${ }^{12}$ Due to the lack of data on some variables included in the equations estimated by 3SLS, we are obliged to use a shorter period.

13 Note that for the exports equation (regressed by OLS) the Breusch-Pagan / Cook-Weisberg test for heteroskedasticity is used.
} 
This relatively high sensitivity of exports on imports ${ }^{14}$ can be a serious shortcoming for the Greek economy in terms of the multiplier effect that exports are expected to have on economic growth. The positive effects of exports on growth can be offset by the high import content of exports. The dependence of exports on imports also shows that exports are of low value-added not contributing expressively to a higher growth.

Although investment and government spending growth are also statistically significant in the import function (the latter at a 5\% level), the import sensitivity of these components of demand is lower than that of exports. Unexpectedly, we were not able to find any significant impact of the growth of consumption on import growth. Relative prices are significant too (but at $10 \%$ level only), displaying a non-sizable impact on imports. This confirms the standard evidence in the literature that imports are more sensitive to changes in the components of income than to price changes.

In the export function our results confirm the standard findings in the literature that exports are income elastic and price inelastic. The income elasticity of the demand for exports is statistically significant at the $1 \%$ level, showing that a 1 p.p. increase in foreign income (OECD countries) is responsible for a 4.540 p.p. increase in exports. This elasticity is surprisingly high, maybe over-estimated, due to the high share that tourism has on exported services. The price elasticity of the demand for exports is not statistically significant but it carries the correct expected positive sign.

Consumption growth is proportional to disposable income growth, growing at the same rate as the latter. The unit elasticity in the consumption function is another drawback of the Greek

\footnotetext{
${ }^{14}$ For comparison purposes, this elasticity has been found to be 0.317 for Portugal (Soukiazis-Cerqueira-Antunes, 2013), 0.439 for Italy (Soukiazis-Cerqueira-Antunes, 2014a), and 0.663 for Slovakia (Soukiazis-MuchovaCerqueira, 2014b).
} 
economy ${ }^{15}$ revealing a constant saving ratio which is very low in this country. Figure 5 shows that the Gross Domestic Saving ratio (as \% of real GDP) in Greece is much lower than the EU or the Eurozone average, and in particular in the period after the financial crisis which is below $10 \%$ in Greece in comparison to above $20 \%$ in the EU or the Eurozone. With such low savings ratio there are not enough domestic resources to finance investment, increasing therefore the necessity for external borrowing.

\section{Insert Figure 5}

With regard to investment, it is shown to be income elastic confirming the well-known accelerator theory. More specifically, the evidence reveals that investment grows 2.610 p.p. for every 1 p.p. increase in real domestic income. Therefore, the accelerator impact is dominant in the investment equation, showing that investment projects are undertaken only when the perspectives on economic growth are fulfilled. On the other hand, the real cost of financing investment projects is not significant in increasing the capital stock.

Having estimated the core parameters of the structural model we are able to compute the growth rate of domestic income in Greece compatible with internal and external constraints as given in equation (14). Table 2 reports these results, where small Greek letters are the elasticities obtained in the estimation approach and all other variables are average growth rates (or shares) for the period 1995-2014. Plugging all these values into equation (14) the estimated growth rate in Greece is equivalent to $0.776 \%$ which is lower than the actual growth $1.055 \%$ observed, and even lower than that predicted from Thirlwall's Law, 2.187\%. The main conclusion to derive here is that the Greek economy grew at a higher rate (1.055\%) than that consistent with internal and external balances $(0.776 \%)$ at the cost of accumulating internal and external deficits. As

\footnotetext{
${ }^{15}$ For comparison, this elasticity is found to be 0.818 in Portugal (Soukiazis-Cerqueira-Antunes, 2013), 0.704 in Italy (Soukiazis-Cerqueira-Antunes, 2014a), and 0.721 in Slovakia (Soukiazis-Muchova-Cerqueira, 2014b).
} 
we can observe the average deficit in the whole period is $w_{D}=7.1 \%$, public debt $w_{B}=119.6 \%$ and current account deficit, $-8.44 \%$ (as percentage of GDP). Therefore, the extended model that also takes into account internal and external constraints makes a more realistic prediction of the Greek growth performance than the Thirlwall's Law that over-predicts economic growth in Greece.

\section{Insert Table 2}

In the following section we will provide some scenarios aiming to detect important policies that could drive the economy to higher growth.

\section{A simulation approach}

As Equation (14) shows, the growth of domestic income depends on a variety of factors able to explain the growth performance in Greece. By using average values over the period 1995-2014, we estimate a low growth in this country equivalent to $0.776 \%$ which is consistent with the internal and external imbalances observed in this period. The extended model can be used to identify factors that could generate higher growth in Greece, serving therefore as policy recommendation. The simulation approach we apply focuses on two main areas aiming to attain internal and external balances.

\section{Towards Internal balance}

(i) Policies to reduce internal imbalances: In Table 2 we observe an average deficit equal to $w_{D}=7.1 \%$ and a public debt equal to $w_{B}=119.6 \%$ for the whole period, violating the Growth and Stability Pact (GSP) of the EU. If we set the GSP targets of $3 \%$ deficit and $60 \%$ debt (other things constant) the estimated growth rate in Greece is around $0.702 \%$ which is slightly lower than the prevailing rate of $0.776 \%$. Reducing simultaneously the share of public spending from the observed rate $w_{G}=0.427 \%$ to $0.30 \%$ the growth rate is even lower, $0.613 \%$. Therefore, 
austerity measures towards fiscal discipline are not growth enhancing. As we explained in the introduction, austerity measures in Greece created a deep economic recession during the Troika intervention, and did not solve the debt problem.

(ii) Lower financial costs: Domestic interest rate is on average $i=8.4 \%$ which is much above the foreign interest $i^{*}=4.0 \%$ (see Table 2). Assuming a more favorable monetary policy of the ECB towards a reduction in the cost of financing the economy, i.e. setting a $2 \%$ interest rate, could help the economy to grow around $0.922 \%$ a bit faster than the observed rate, $0.776 \%$.

(iii) Higher taxes and lower government spending: The austerity measures imposed by Troika in Greece were seeking to reduce government spending and increase taxes in order to control public deficit. If taxes on income increase from the average rate $t=38.7 \%$ to $45 \%$ and government spending (as percentage of GDP) falls from the average rate $\mathrm{wG}_{\mathrm{G}}=42.7 \%$ to $30 \%$, income growth falls from $0.776 \%$ to $0.611 \%$. Again, as it is expected, austerity measures are not friendly to higher growth.

\section{Towards External balance}

(i) Policies to reduce the exports sensitivity on imports: From the estimation approach (see Table D.1) we have concluded that one of the main concern of the Greek economy has to do with the high income elasticity found in the import equation with respect to exports, $\pi_{x}=0.712$. Reducing this high sensitivity of exports on imports to $\pi_{x}=0.60$, and plugging this value to equation (14), the estimated growth rate in Greece boosts from the prevailing rate of $0.776 \%$ (see Table 2) to $1.666 \%$ which is a significant achievement. Therefore, policies should be developed to encourage the use of national inputs in the export sector. 
(ii) Policies towards a trade balance: As Table 2 shows the share of exports $w_{X}=23.06 \%$ is lower than the share of imports $w_{M}=33.10 \%$, thus explaining the high current account deficit in Greece (being on average of -8.44 over GDP). Equalizing the exports share to that of imports (other things constant) the estimated growth rate increases to $3.828 \%$, or alternatively, reducing the imports share to the exports level the growth rate increases to $4.106 \%$, which are both remarkable achievements. Therefore policies towards trade balance boost economic growth in Greece.

(iii) Constant relative prices: If we assume that relative prices stay constant in the longrun, that is, $p^{*}+\dot{e}-\dot{p}=0$, and therefore $\left(\mathrm{P}^{*} \mathrm{e}\right) / \mathrm{P}=1$, then the estimated growth slightly drops from the observed average value $0.776 \%$ to $0.741 \%$. Two main remarks can be made with respect to this finding. First, relative prices are not neutral in the growth process. Second, although price stability is not favoring higher growth, its impact on growth is not very substantial. This finding is in line with Thirlwall's argument that international competition is mostly non-price competition.

\section{Conclusions and policy implications}

In this study we apply two demand orientated approaches to explain the growth performance in Greece over the period 1995-2014. The first growth approach is based on the well-known Thirlwall's Law that defines the growth rate consistent with the balance-of-payments equilibrium, arguing that unsustainable current account deficits put a limit on demand and therefore on growth. Applying this approach to the Greek economy, we show that the model over-predicts the growth rate observed in this country, and this is not consistent with the external imbalances (on current account) experienced over time. The lack of accuracy of Thirlwall's Law to the Greek reality can be attributed mainly to two factors. The model assumes that relative prices are constant in the long-run, but mostly it does not consider internal imbalances caused by excessive public deficit and debt. 
The second approach we use is an extension of Thirlwall's model that takes into account not only external but also internal constraints (the twin-deficit hypothesis) and relaxes the assumption that relative prices are neutral in the long-run growth. Additionally, we decompose aggregate income by its main components in order to measure their dependence on imports. Applying the extended model to the Greek economy we show that it makes a more realistic prediction, showing that the Greek economy grew faster than the rate consistent with internal and external balances. Our conclusion is more consistent with the high public deficit and debt, and current account deficit observed over the period considered.

Implementing an efficient estimation approach based on 3SLS that controls for the endogeneity of regressors and the cross-equation error correlation, we found some important shortcomings that characterize the Greek economy. First, a high sensitivity of exports on imports that might harm the positive effects of exports on growth. Second, a unit elasticity of consumption with respect to disposable income which reveals in fact a constant saving ratio in this country. Historical data shows that the saving ratio in Greece is almost half than the EU average, leaving insufficient domestic resources to finance investment plans, and therefore the necessity for higher borrowing from abroad. Third, income elasticity of the demand for exports is unusually high which can be explained by the high importance of tourism on exported services.

Finally, the simulation approach applied to the extended model highlights the following aspects. The most efficient policy to achieve higher growth in Greece is related to external imbalances and to a less extent to internal imbalances. Namely, higher growth is attained by reducing the exports sensitivity on imports and by encouraging policies that could bring into balance the import and export shares. Although relative prices stability is desirable for growth, its impact on growth is not very substantial. The Growth and Stability Pact 
requirements are not growth enhancing neither an aggressive tax policy nor a contraction in government spending. Better financial conditions (lower interest rates) are beneficial to growth but have a modest impact. 


\section{References}

- Antunes, M., and E.,Soukiazis, 2009. "How well the balance of payments constrained approach explains the Portuguese growth performance. Empirical evidence for the 1965-2008 period". GEMF Working Paper, No. 13, Portugal.

- Alesina, A., and R. Perotti, 1996. "Fiscal adjustments in OECD countries: composition and macroeconomic effects.” NBER Working Paper No. 5730 (August).

- Alonso, J.A., and C. Garcimartin, 1999. "A new approach to balance-of-payments constrained growth model.” Journal of Post Keynesian Economics. 21(2): 259-282.

- Atesoglou, H.S., 1997. "Balance of payments constrained growth model and its implications for the United States." Journal of Post Keynesian Economics. 19(3): 327-335.

- Blecker, R. 2009. "Long-run growth in open economies: export-led cumulative causation or a balance-of-payments constraint?" $2^{\text {nd }}$ summer school on Keynesian Macroeconomics and European Economic Policies, August, Berlin.

- Boggio, L.; Barbieri, L., 2016. "International competitiveness in post-Keynesian growth theory: controversies and empirical evidence". Cambridge Journal of Economics, 1-23. doi:10.1093/cje/bev067

-Brissimis, S.N., G. Hondroyiannis, C. Papazoglou, T. Tsaveas, and M.A. Vasardani, 2010. “Current account determinants and external sustainability in period of structural change." ECB Working Paper. No.1243/2010.

-Cardoso, C., and E. Soukiazis, 2005. "Explaining the uneven economic performance of the cohesion countries. An export-led growth approach.” Discussion Paper No. 32. Coimbra.

- Felipe, J., J.S.L. McCombie, and K. Naqvi, 2009. "Is Pakistan's Growth Rate Balance-ofPayments Constrained? Policies and Implications for Development and Growth." $A D B$ Economics Working Papers No. 160.

- Heike, H., 1997. "Balance of payments constrained growth: A reconsideration of the Evidence for the U.S. economy.” Journal of Post Keynesian Economics. 19(3): 313-325. 
-Hondroyiannis, G., and D. Papaoikonomou, 2014. "When does it pay to tax? Evidence from statedependent fiscal multipliers in the Euro area." Economic Modelling. 48: 116-128.

-Hussein, K., and A.P. Thirlwall, 2000. "The AK model of "new" growth theory is Harrod-Domar growth equation: investment and growth revisited." Journal of Post Keynesian Economics. 22(3): 427.

- Garcimartin, C., L. Rivas, and P. Martinez, P., 2011. "On the role of relative prices and capital flows in balance-of-payments constrained growth: the experiences of Portugal and Spain in the Euro Area." Journal of Post Keynesian Economics 33(2): 281-306.

-Katsimi, M., and T. Moutos, 2010. "EMU and the Greek crisis: The political-economy perspective." European Journal of Political Economy. 26: 568-576.

- Lopez, J., and A. Cruz, 2000. "Thirlwall's law and beyond: The Latin American experience." Journal of Post Keynesian Economics. 22(3): 477-495.

-Mavroudeas, S.D., 2010. "Greek scientific association of political economy." 1st International Conference in Political Economy. 10-12/09/2010, Rethymnon, Greece.

- McCombie, J., 1985. "Economic growth, the Harrod foreign trade multiplier and the Hick's super-multiplier." Applied Economics. 17: 55-72.

- McCombie, J., and A.P. Thirlwall, 1994. "Economic growth and the balance-of-payments constraint.” MacMillan Press, Basingstoke; St. Martin's Press, New York.

- McGregor, P., and J. Swales, 1985. "Professor Thirlwall and the balance-of-payments constrained growth." Applied Economics. 17: 17-32.

- McGregor, P., anf J. Swales, 1991. “Thirlwall's Law and balance-of-payments constrained growth: further comment on the debate." Applied Economics. 23: 9-23.

- Moreno-Brid, J., 1999. "On capital flows and the balance-of-payments-constrained growth model." Journal of Post Keynesian Economics. 21(2): 283-298.

- Palley, I.T., 2010. "Imports and the income-expenditure model: implications for fiscal policy and recession fighting." Journal of Post Keynesian Economics. 32(2): 311-322. 
- Pelagidis, T., and E. Desli, 2004. "Deficits, growth and the current slowdown: what role for fiscal policy?" Journal of Post Keynesian Economics. 26(3): 461-469..

- Pindyck, R.,S., and Rubinfeld, D., L., 1991. "Econometric Models and Economic Forecasts", $3^{\text {rd }}$ Edition, McGraw-Hill, International Editions.

- Podkaminer, L., 2015. “Thirlwall’s Law” reconsidered. Empirica. 6: 1-29.

- Ramzi, A., 2005. "Balance of payments constrained growth model: The case of India." Working Paper No. 2005-05, EDWPS, University of Massachusetts.

- Rapetti, M.; Skott, P.; Razmi, A., 2012. "The real exchange rate and economic growth: are developing countries different?". International Review of Applied Economics, 26 (6), 735-753. http://dx.doi.org/10.1080/02692171.2012.686483

- Rodrik, D., 2008. "The real exchange rate and economic growth". Brooking Papers on Economic Activity, Fall, 365-439.

- Romero, J.P., and J.S.L. McCombie, 2014. "The multi-Sectoral Thirlwall's Law: Evidence from 14 Developed European Countries using Product Level Data.” Working Paper Series. CCEPP No.04, University of Cambridge.

- Solow, R.M., 1956. “A Contribution to the Theory of Economic Growth.” Quarterly Journal of Economics. 70: 65-94.

- Soukiazis, E., P. Cerqueira P., and M. Antunes, 2012. "Modelling economic growth with internal and external imbalances: empirical evidence from Portugal." Economic Modelling. 29(2): 478486.

- Soukiazis, E., P.A., Cerqueira, and M. Antunes, 2013. "Growth rates constrained by internal and external imbalances and the role of relative prices: empirical evidence from Portugal." Journal of Post Keynesian Economics. 36(2): 275-298

- Soukiazis, E., P.A., Cerqueira, and M. Antunes, 2014a. "Explaining Italy’s economic growth: A balance-of-payments approach with internal and external imbalances and non-neutral relative prices." Economic Modelling. 40: 334-341. 
- Soukiazis, E., E., Muchova, E., and P.A. Cerqueira, 2014b. "Is the Slovak economy doing well? A twin deficit growth approach." GEMF Working Paper No. 08, Portugal.

- Soukiazis, E., M. Antunes, and A. Stoian, 2015. "The effect of internal and external imbalances on Romanian's economic growth.” MPRA Paper No. 63558.

- Thirlwall, A., 1979. "The balance-of-payments constraint as an explanation of international growth rate differences." Banca Nazionale del Lavoro. 128: 45-53.

- Thirlwall, A., 1982. "The Harrod trade multiplier and the importance of export-led growth." Pakistan Journal of Applied Economics. 1(1): 1-21.

- Thirlwall, A., and N. Hussain, 1982. "The balance-of-payments constraint, capital flows and growth rate differences between developing countries." Oxford Economic Papers. 34: 498-510.

- Wooldridge, J. 2002. "Econometric analysis of cross-section and panel data." Cambridge. Massachusetts. MIT Press. 
Figure 1. Real growth of GDP and public deficit (as \% of GDP), Greece 1981-2014

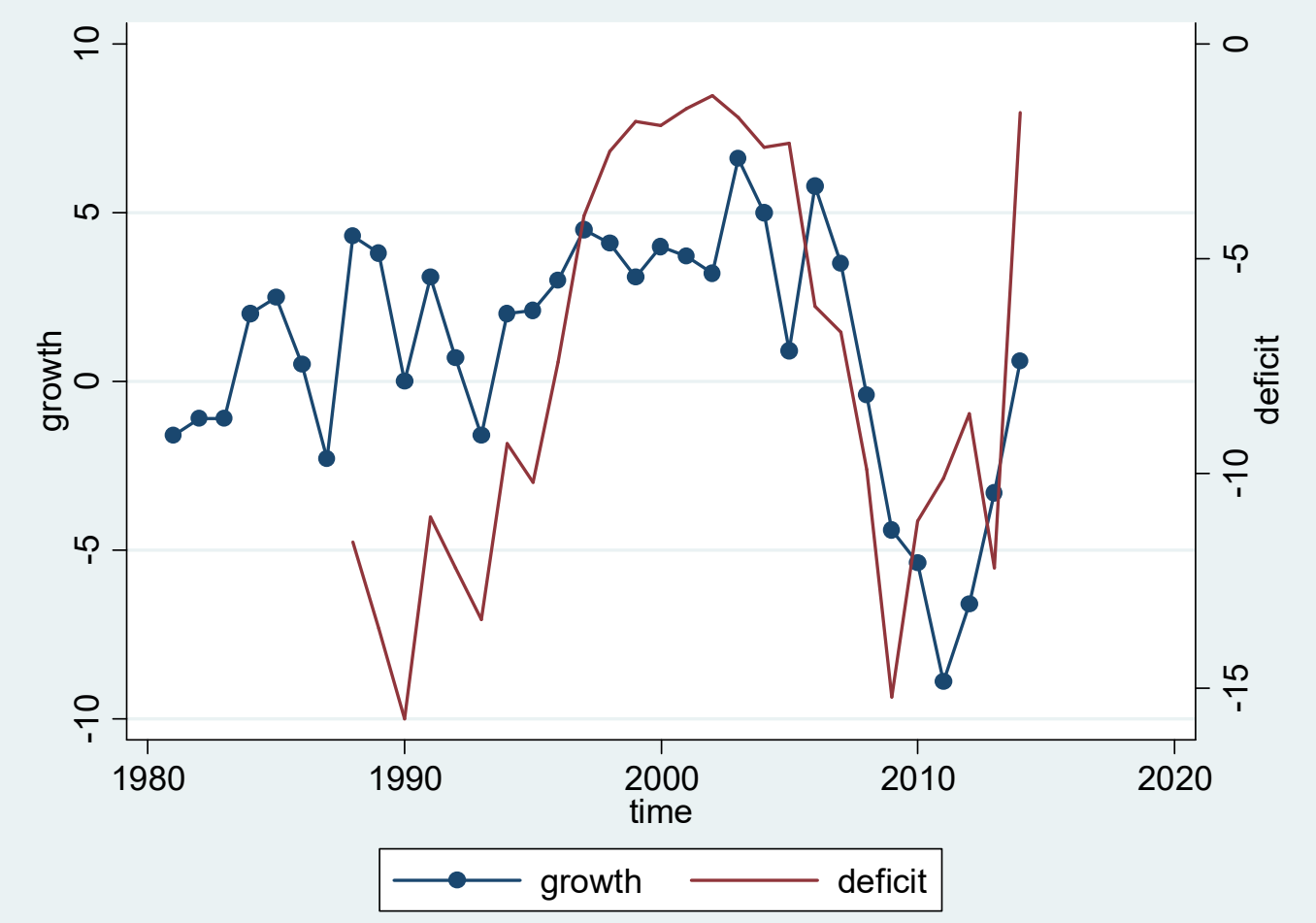

Data Source: Ameco

Figure 2. Real growth of GDP and public debt (as \% of GDP), Greece, 1981-2014

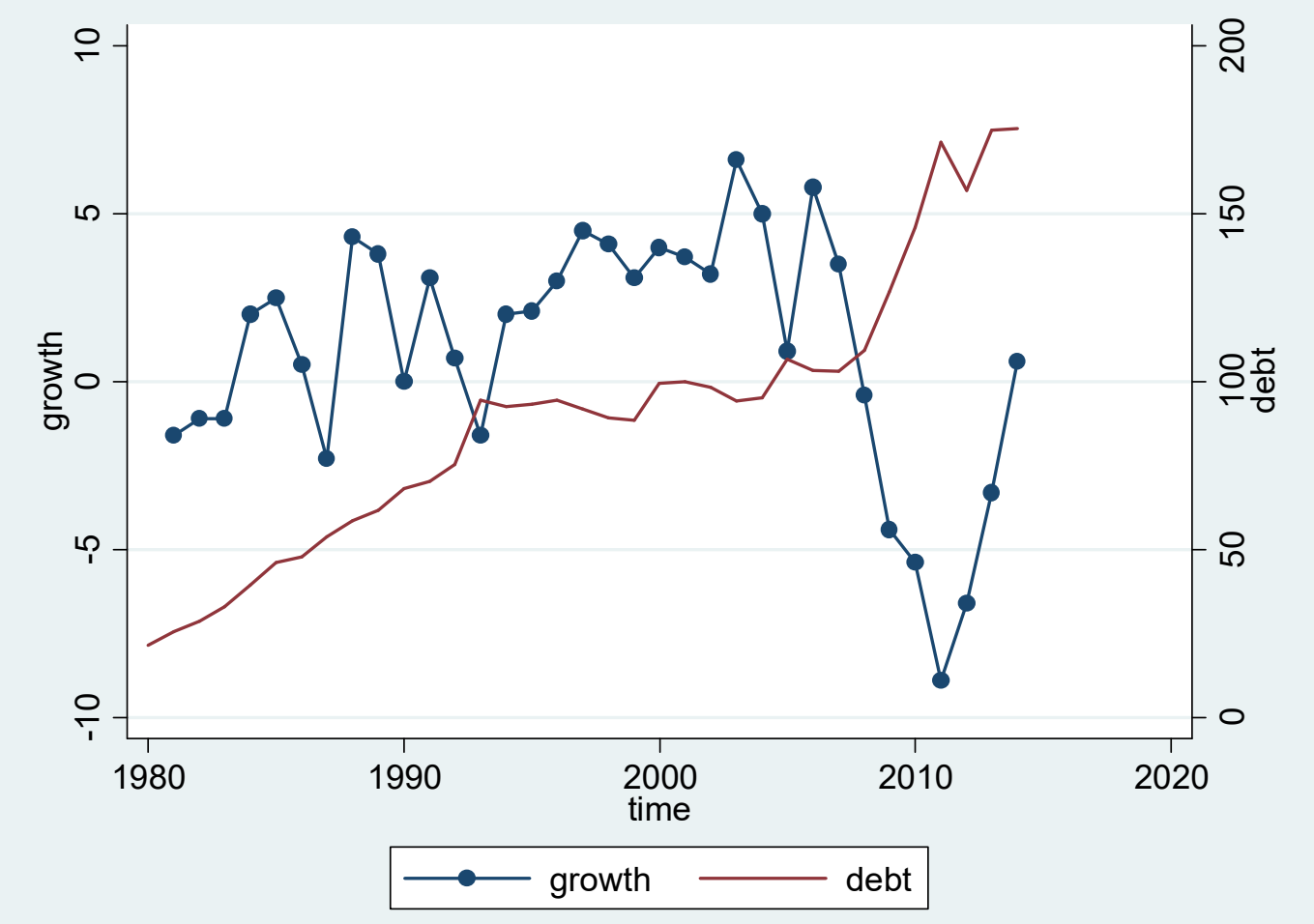

Data Source: Ameco 
Figure 3. GDP growth and the Current Account (as \% of GDP), Greece, 1981-2014

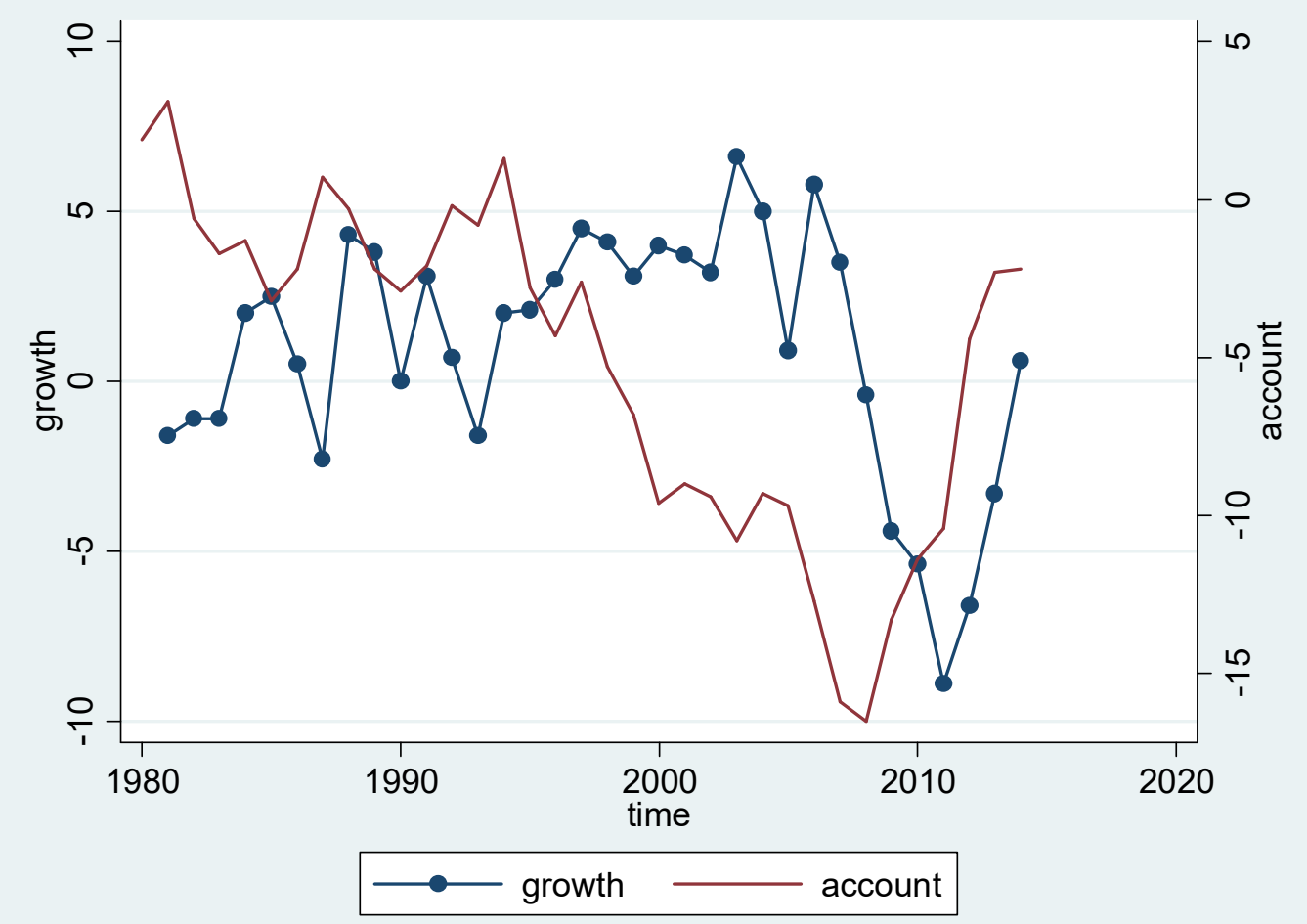

Data Source: Ameco 
Figure 4: Growth rates of Investment, Consumption, Imports and Exports, Greece, 1981-2014
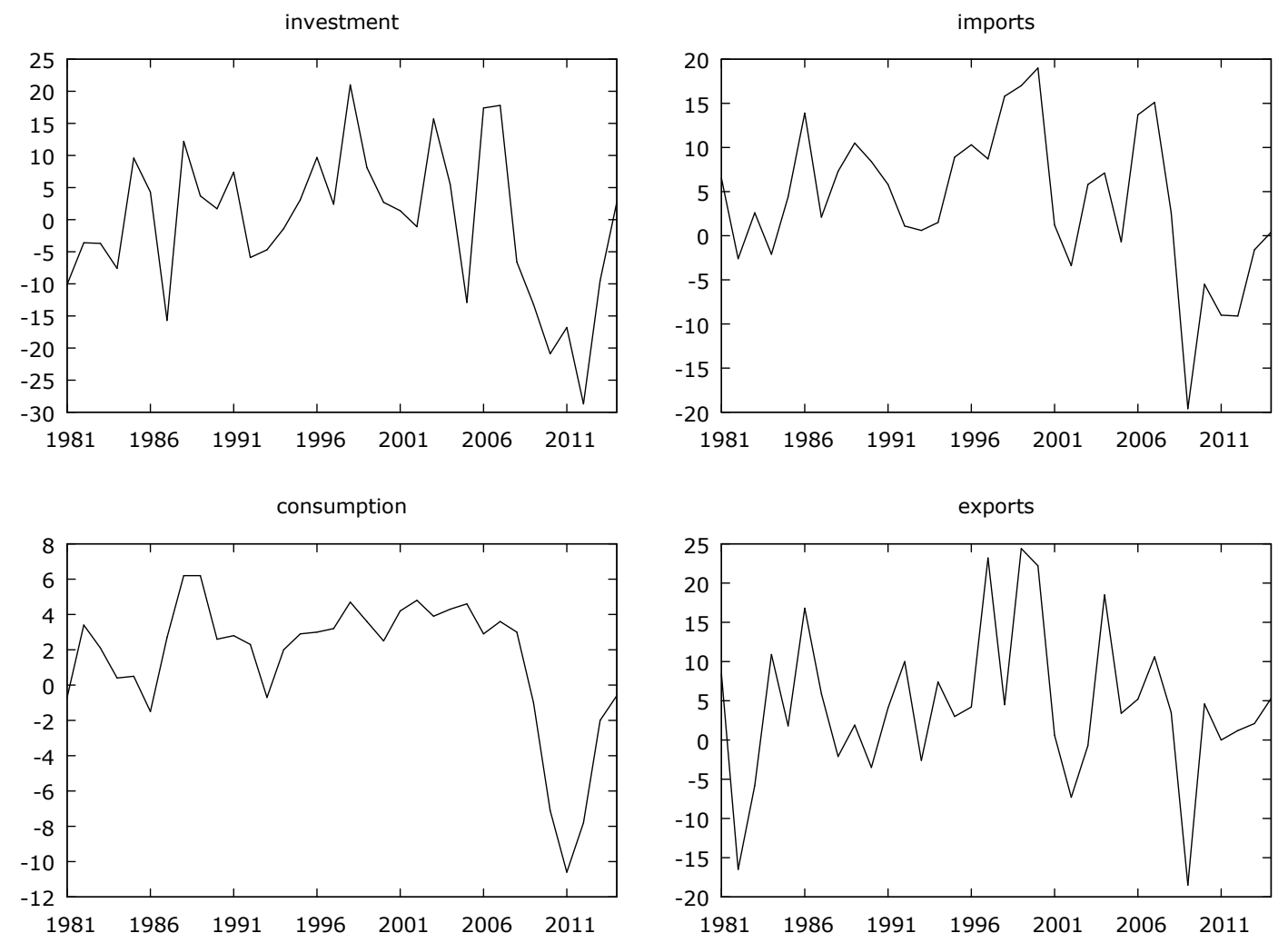

Data Source: Ameco 
Figure 5. Saving ratio in Greece, the Eurozone and EU, 1990-2015

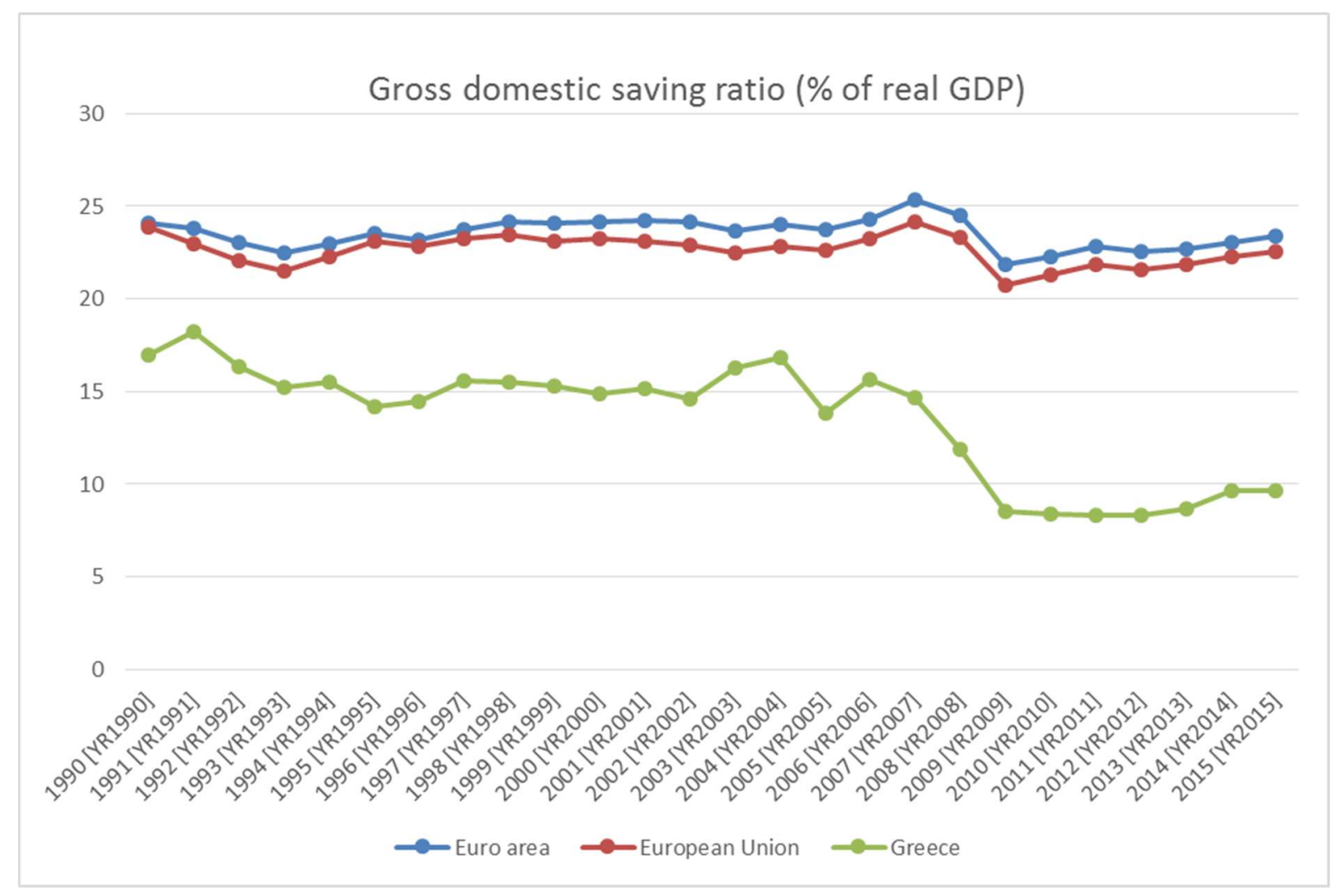

Data Source: OECD National accounts 
Table 1. Computation of the balance of payments equilibrium growth rate in Greece, 1995-2014.

\begin{tabular}{|c|l|l|l|l|l|l|l|l|}
\hline$\dot{x}$ & $\pi$ & $\varepsilon$ & $\dot{y}^{*}$ & $\dot{y}_{B P}=\frac{\dot{x}}{\pi}$ & $\dot{y}_{B P}=\frac{\varepsilon}{\pi} \dot{y}^{*}$ & $\dot{y}$ & $\dot{y}^{-} \dot{y}_{B P}$ & $\begin{array}{l}\text { Current } \\
\text { account } \\
(\% \text { GDP })\end{array}$ \\
\hline 4.080 & 1.865 & & & 2.188 & & 1.055 & -1.132 & -8.44 \\
\hline & & 4.518 & 2.154 & & 5.218 & & -4.319 & \\
\hline
\end{tabular}

Notes: $\dot{x}$ is the annual growth of real exports, $\pi$ the income elasticity of the demand for imports, $\varepsilon$ the income elasticity of the demand for exports, $\dot{y}^{*}$ the growth rate of real GDP of the OECD countries, $\dot{y}$ the growth rate of real GDP in Greece, and $\dot{y}_{B P}$ the balance of payments equilibrium growth rate (own calculations).

Table 2. Computation of the growth rates of domestic income. Greece, 1995-2014

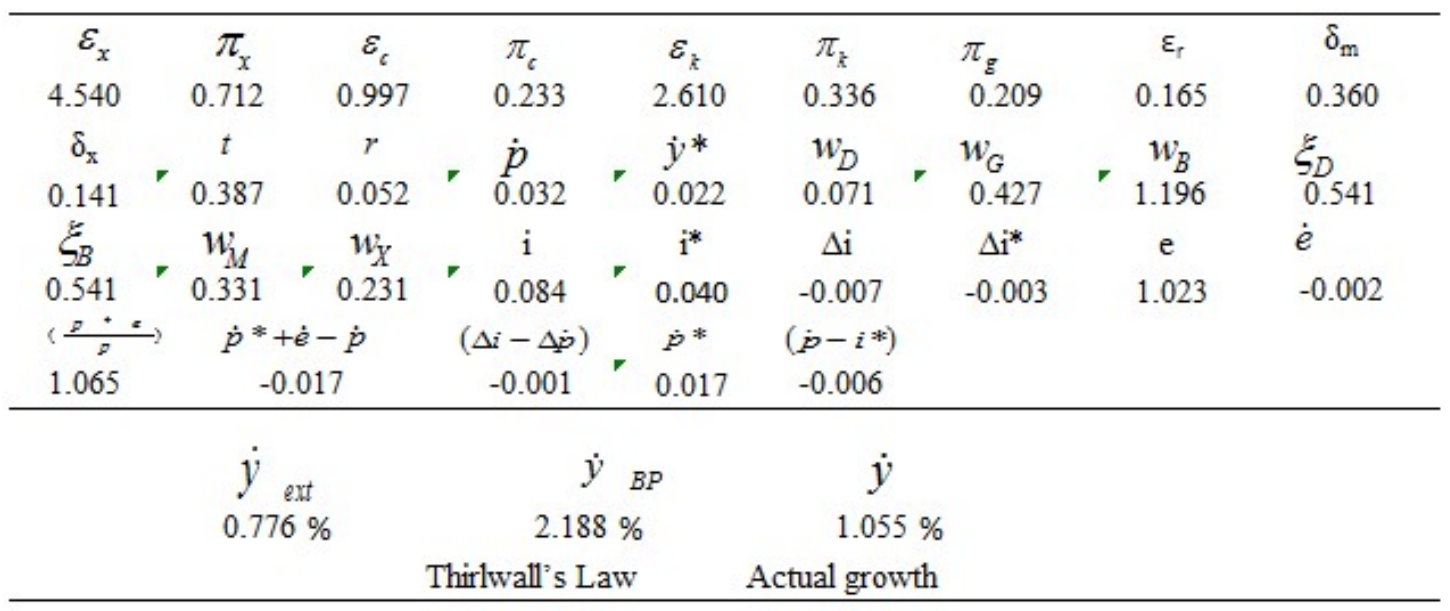

Notes: small Greek letters are the elasticities taken from Table D.1 of Appendix D and other variables are average growth rates for the whole period. $\xi_{D}$ and $\xi_{B}$ was computed by the authors as an average for the period 1997:4 to 2013:4 (Central Bank of Greece) - http://www.bankofgreece.gr/Pages/en/Statistics/accounts.aspx 
Table A. Internal and External Imbalances in Greece

\begin{tabular}{|c|c|c|c|c|}
\hline time & $\begin{array}{l}\text { GDP } \\
\text { growth }\end{array}$ & Deficit \% & Debt \% & $\begin{array}{c}\text { Current } \\
\text { account } \%\end{array}$ \\
\hline 1980 & & & 21.4 & 1.9 \\
\hline 1981 & -1.6 & & 25.4 & 3.1 \\
\hline 1982 & -1.1 & & 28.7 & -0.6 \\
\hline 1983 & -1.1 & & 33 & -1.7 \\
\hline 1984 & 2 & & 39.3 & -1.3 \\
\hline 1985 & 2.5 & & 46 & -3.2 \\
\hline 1986 & 0.5 & & 47.7 & -2.2 \\
\hline 1987 & -2.3 & & 53.7 & 0.7 \\
\hline 1988 & 4.3 & -11.6 & 58.6 & -0.3 \\
\hline 1989 & 3.8 & -13.6 & 61.7 & -2.2 \\
\hline 1990 & 0 & -15.7 & 68.2 & -2.9 \\
\hline 1991 & 3.1 & -11 & 70.4 & -2.1 \\
\hline 1992 & 0.7 & -12.2 & 75.3 & -0.2 \\
\hline 1993 & -1.6 & -13.4 & 94.4 & -0.8 \\
\hline 1994 & 2 & -9.3 & 92.5 & 1.3 \\
\hline 1995 & 2.1 & -10.2 & 93.2 & -2.8 \\
\hline 1996 & 3 & -7.4 & 94.6 & -4.3 \\
\hline 1997 & 4.5 & -4 & 91.8 & -2.6 \\
\hline 1998 & 4.1 & -2.5 & 89.2 & -5.3 \\
\hline 1999 & 3.1 & -1.8 & 88.5 & -6.8 \\
\hline 2000 & 4 & -1.9 & 99.6 & -9.6 \\
\hline 2001 & 3.7 & -1.5 & 100.1 & -9 \\
\hline 2002 & 3.2 & -1.2 & 98.3 & -9.4 \\
\hline 2003 & 6.6 & -1.7 & 94.3 & -10.8 \\
\hline 2004 & 5 & -2.4 & 95.1 & -9.3 \\
\hline 2005 & 0.9 & -2.3 & 106.8 & -9.7 \\
\hline 2006 & 5.8 & -6.1 & 103.4 & -12.7 \\
\hline 2007 & 3.5 & -6.7 & 103.1 & -15.9 \\
\hline 2008 & -0.4 & -9.9 & 109.3 & -16.5 \\
\hline 2009 & -4.4 & -15.2 & 126.8 & -13.3 \\
\hline 2010 & -5.4 & -11.1 & 146 & -11.4 \\
\hline 2011 & -8.9 & -10.1 & 171.3 & -10.4 \\
\hline 2012 & -6.6 & -8.6 & 156.9 & -4.4 \\
\hline 2013 & -3.3 & -12.2 & 174.9 & -2.3 \\
\hline 2014 & 0.6 & -1.6 & 175.5 & -2.2 \\
\hline \multicolumn{5}{|c|}{ Average rates } \\
\hline 1981-2014 & 0.95 & $-7.6^{(\mathrm{a})}$ & 91.57 & -5.32 \\
\hline $1981-2000$ & 1.6 & $-8.81^{(b)}$ & 67.59 & -2.19 \\
\hline 2001-2014 & 0.02 & -6.47 & 125.84 & -9.81 \\
\hline
\end{tabular}

Notes: ${ }^{(a)}$ period 1988-2014, ${ }^{(b)}$ period 1988-2000

Data Source: Ameco 


\section{Appendix B}

Table B.1. The estimation of the import and export demand functions, Greece, 1995-2014.

\begin{tabular}{|c|c|c|}
\hline & Imports(OLS) & Exports(OLS) \\
\hline constant & 0.796 & $-5.575^{* *}$ \\
& $(0.575)$ & $(0.014)$ \\
\hline$\dot{y}_{\boldsymbol{t}}$ & $1.865^{* * *}$ & \\
& $(0.000)$ & \\
\hline$\left(\dot{\boldsymbol{p}}_{\boldsymbol{t}} *+\dot{\boldsymbol{e}}_{\boldsymbol{t}}-\dot{\boldsymbol{p}}_{\boldsymbol{t}}\right)$ & 0.837 & 0.191 \\
& $(0.125)$ & $(0.673)$ \\
\hline$\dot{\boldsymbol{y}}_{\boldsymbol{t}} *$ & & $4.518^{* * *}$ \\
& & $(0.000)$ \\
\hline $\mathrm{R}^{2}$ & 0.665 & 0.695 \\
& $\mathrm{~F}(2,17)=16.87$ & $\mathrm{~F}(2,17)=19.33$ \\
& $(0.000)$ & $(0.000)$ \\
\hline F-test (joint significance) & $\chi_{1}^{2}=0.316$ & $\chi_{1}^{2}=0.521$ \\
& $(0.574)$ & $(0.471)$ \\
\hline LM-test (serial correlation) & $\mathrm{F}(3,14)=1.50$ & $\mathrm{~F}(3,14)=2.32$ \\
& $(0.258)$ & $(0.120)$ \\
\hline Reset (model specification)
\end{tabular}

Notes: $\dot{y}$ is real GDP annual growth rate of Greece, $\dot{y}^{*}$ is real GDP annual growth of the OECD countries, and $\left(\dot{\boldsymbol{p}}_{t} *+\dot{\boldsymbol{e}}_{t}-\dot{\boldsymbol{p}}_{t}\right)$ is the annual growth of the real effective exchange rate.

$*, * *, * * *$ Coefficient significant at the $10 \%, 5 \%$ and $1 \%$ level, respectively.

Numbers in parentheses are $\mathrm{p}$-values. 


\section{Appendix C: Description of the variables and data sources}

- $\quad \dot{m}_{t}-$ annual growth rate of real imports - Imports of goods and services at 2000 prices (national currency; annual percentage change).

- $\quad \dot{c}_{t}$ - annual growth rate of final private consumption - Private final consumption expenditure at 2000 prices (national currency; annual percentage change).

- $\dot{x}_{t}-$ annual growth rate of real exports - Exports of goods and services at 2000 prices (national currency; annual percentage change).

- $\dot{k}_{t}-$ annual growth rate of investment - Gross fixed capital formation at 2000 prices (national currency; annual percentage change).

- $\quad \dot{y}_{t}$ - annual growth rate of real GDP - GDP at 2000 market prices (national currency; annual percentage change).

- $\quad \dot{p}_{t}$ - annual growth rate of price deflator GDP at market prices (national currency; annual percentage change).

- $\dot{p}_{t}^{*}$ _ annual growth rate of price deflator GDP at market prices, for the EU-12 (national currency; annual percentage change).

- $w_{D}$ - share of government's deficit on GDP - Net lending (-) or net borrowing (+); general government ( $\%$ of GDP at market prices; excessive deficit procedure).

- $w_{B}$ - share of government's debt on GDP - General government consolidated gross debt (\% of GDP at market prices; excessive deficit procedure).

- $w_{M}$ - imports of goods and services at current prices (national accounts) - \% of GDP at market prices

- $w_{X^{-}}$. exports of goods and services at current prices (national accounts) - \% of GDP at market prices.

- $t$ - share of government's revenues on GDP - Total current revenue; general government ( $\%$ of GDP at market prices; excessive deficit procedure).

- $i$ - nominal long-term interest rates $(\%)$

- $i^{*}$ - nominal long-term interest rates $(\%)$ for Germany

Data on $\dot{m}_{t}, \dot{c}_{t}, \dot{x}_{t}, \dot{k}_{t}, \dot{y}_{t}, \dot{p}_{t}, \dot{p}_{t}^{*}, w_{D}, w_{B}, w_{M}, w_{X}, t, i$ and $i^{*}$ were taken from the Statistical Annex of European Economy, Spring 2015, released by the European Commission (http://ec.europa.eu/economy finance/publications/european_economy/2015/pdf/2015 $05 \quad 05$ stat annex en.pdf.)

- $w_{G}$ - share of government's expenditure on GDP - Total expenditure excluding interest: general government ( $\%$ of GDP at current prices (excessive deficit procedure)).

Data extracted from Ameco, http://ec.europa.eu/economy finance/ameco/user/serie/ResultSerie.cfm, on $5^{\text {th }}$ May 2016.

- $\quad \dot{g}_{t}-$ annual growth rate of government's expenditure. Computed by the authors from data on "Real total expenditure of general government, deflator GDP", from Ameco, http://ec.europa.eu/economy finance/ameco/user/serie/ResultSerie.cfm

- $\dot{y}^{*}$ - annual growth rate of real foreign income (OECD countries). Computed by the authors using information about "Gross domestic product, GDP per head, US \$, constant prices, constant PPPs, reference year 2005", from OECD StatExtracts - http://stats.oecd.org/ (extracted on $15^{\text {th }}$ December 2011)

- $\dot{y}_{d}$ - annual growth rate of disposable income (OECD) 
- $e$-nominal effective exchange rate - price of domestic currency in terms of foreign currency - index $(2010=100)$ broad indices (61 countries). Computed by the authors using monthly data, from the Bank for International Settlements(BIS)- http://www.bis.org/statistics/eer.htm (2015)

- $\left(P^{*} e / P\right)$ - real effective exchange rate index $(2010=100)$, broad indices (61 countries). Computed by the authors using monthly data, from the Bank for International Settlements(BIS)http://www.bis.org/statistics/eer.htm (2015)

\section{Appendix D}

Table D.1. The 3SLS estimation of the structural model. Greece, 1995-2014.

\begin{tabular}{|c|c|c|c|c|c|c|c|}
\hline \multirow[b]{2}{*}{ 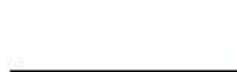 } & \\
\hline & Coefficient & Std Error & t-stat & p-value & $\mathrm{R}^{2}$ & F-stat & p-ralue \\
\hline \multicolumn{8}{|l|}{ Imports growth } \\
\hline constant & -1.367 & 0.658 & -2.08 & $0.042 * *$ & \multirow{6}{*}{0.9280} & \multirow{6}{*}{72.73} & \multirow{6}{*}{0.000} \\
\hline$\dot{c}_{t}$ & 0.233 & 0.213 & 1.09 & 0.278 & & & \\
\hline$\dot{g}_{t}$ & 0.209 & 0.081 & 2.57 & $0.012^{* *}$ & & & \\
\hline$\dot{\boldsymbol{x}}_{t}$ & 0.712 & 0.065 & 10.97 & $0.000 * * *$ & & & \\
\hline$t n v_{t}$ & 0.336 & 0.084 & 4.02 & $0.000 * * *$ & & & \\
\hline$\left(\dot{\boldsymbol{p}}_{t} \times+\dot{\boldsymbol{e}}_{t}-\dot{\boldsymbol{p}}_{t}\right)$ & 0.360 & 0.181 & 1.99 & $0.051^{*}$ & & & \\
\hline \multicolumn{8}{|c|}{ Consumption growth } \\
\hline constant & -0.085 & 0.455 & -0.19 & 0.852 & \multirow{2}{*}{0.8163} & \multirow{2}{*}{90.87} & \multirow{2}{*}{0.000} \\
\hline$\dot{\boldsymbol{y}}_{d, t}$ & 0.997 & 0.105 & 9.53 & $0.000 * * *$ & & & \\
\hline \multicolumn{8}{|l|}{ Investment growth } \\
\hline constant & -1.908 & 1.408 & -1.36 & 0.180 & \multirow{3}{*}{0.7781} & \multirow{3}{*}{32.54} & \multirow{3}{*}{0.000} \\
\hline$\dot{y}_{t}$ & 2.610 & 0.341 & 7.64 & $0.000^{* * *}$ & & & \\
\hline$\dot{r}_{t}$ & 0.165 & 0.349 & 0.47 & 0.638 & & & \\
\hline \multicolumn{8}{|l|}{ Exports growth } \\
\hline constant & -5.519 & 1.878 & -2.94 & $0.005 * * *$ & \multirow{3}{*}{0.6978} & \multirow{3}{*}{23.46} & \multirow{3}{*}{0.000} \\
\hline$\dot{y}_{t} *$ & 4.540 & 0.689 & 6.59 & $0.000 * * *$ & & & \\
\hline$\left(\dot{p}_{t}{ }^{*}+\dot{e}_{t}-\dot{p}_{t}\right)$ & 0.141 & 0.413 & 0.34 & 0.734 & & & \\
\hline
\end{tabular}

\section{Notes to the tables:}

Endogenous variables: $\dot{m}_{t}, \dot{c}_{t}, l \dot{n} v_{t}, \dot{x}_{t}, \dot{g}_{t}, \dot{y}_{t}, \dot{y}_{d, t}, \dot{r}_{t}$,

Exogenous variables: $\left(\dot{p}_{t} *+\dot{e}_{t}-\dot{p}_{t}\right), \dot{y}^{*}, t_{t}, i_{t}, i_{t}^{*}, p^{*} t, \dot{p}_{t-1} \dot{c}_{t-1}, \dot{g}_{t-1}, \dot{x}_{t-1}, w_{D, t}$

$*, * *, * * *$ Coefficient significant at the $10 \%, 5 \%$ and $1 \%$ level, respectively 
Table D.2. The 2SLS estimation of each equation of the structural model. Greece, 19952014.

\begin{tabular}{|c|c|c|c|c|c|c|c|c|}
\hline & & & & & & & & \\
\hline & & & & & Sargan & Heteroskedasticity & & \\
\hline & Coefficient & Std Error & t-stat & p-value & test & test & AR(1) test & Normality test \\
\hline \multicolumn{9}{|l|}{ Imports growth } \\
\hline constant & -2.468 & 1.785 & -1.38 & 0.190 & \multirow{6}{*}{$\begin{array}{c}\chi^{2} \sigma=5.214 \\
\text { p-value }=0.517\end{array}$} & \multirow{6}{*}{$\begin{array}{c}x^{2} 11=5.513 \\
\text { p-value }=0.904\end{array}$} & \multirow{6}{*}{$\begin{array}{c}\chi^{2}{ }_{1}=0.128 \\
\text { p-value }=0.720\end{array}$} & \multirow{6}{*}{$\begin{array}{c}\mathrm{X}^{2}{ }_{2}=2.78 \\
\text { p-value }=0.245\end{array}$} \\
\hline$\dot{\boldsymbol{c}}_{t}$ & 0.332 & 0.349 & 0.95 & 0.359 & & & & \\
\hline$\dot{\boldsymbol{g}}_{t}$ & 0.201 & 0.134 & 1.50 & 0.158 & & & & \\
\hline$\dot{x}_{\boldsymbol{t}}$ & 0.645 & 0.105 & 6.16 & $0.000 * * *$ & & & & \\
\hline $\operatorname{lnv} v_{t}$ & 0.322 & 0.135 & 2.38 & $0.033 * *$ & & & & \\
\hline$\left(\dot{\boldsymbol{p}}_{t} *+\dot{\boldsymbol{e}}_{t}-\dot{\boldsymbol{p}}_{t}\right)$ & 0.329 & 0.285 & 1.15 & 0.270 & & & & \\
\hline \multicolumn{9}{|l|}{ Consumption growth } \\
\hline constant & -0.090 & 0.484 & -0.19 & 0.855 & \multirow{2}{*}{$\begin{array}{c}\chi^{2} g=11.471 \\
\text { p-value }=0.245\end{array}$} & $\chi^{2} 10=6.716$ & \multirow{2}{*}{$\begin{array}{c}x^{2}{ }_{1}=0.766 \\
\text { p-value }=0.381\end{array}$} & \multirow{2}{*}{$\begin{array}{c}X_{2}^{2}=2.40 \\
\text { p-value }=0.300\end{array}$} \\
\hline$\dot{\boldsymbol{y}}_{d, t}$ & 1.002 & 0.112 & 8.92 & $0.000 * * *$ & & p-value $=0.752$ & & \\
\hline \multicolumn{9}{|l|}{ Investment growth } \\
\hline constant & -1.975 & 1.541 & -1.28 & 0.218 & \multirow{3}{*}{$\begin{array}{c}x^{2} 8=3.549 \\
p \text {-value }=0.895\end{array}$} & $x_{10}^{2}=8.495$ & \multirow{3}{*}{$\begin{array}{c}X^{2}{ }_{1}=0.166 \\
\text { p-value }=0.684\end{array}$} & \multirow{3}{*}{$\begin{array}{c}\mathrm{X}_{2}^{2}=3.73 \\
\text { p-value }=0.156\end{array}$} \\
\hline$\dot{y}_{\varepsilon}$ & 2.673 & 0.394 & 6.78 & $0.000 * * *$ & & $p$-value $=0.581$ & & \\
\hline$\dot{r}_{t}$ & 0.335 & 0.474 & 0.71 & 0.490 & & & & \\
\hline \multicolumn{9}{|l|}{ Exports growth } \\
\hline \multirow{3}{*}{$\begin{array}{c}\text { constant } \\
\dot{y}_{t}^{*} \\
\left(\dot{\boldsymbol{p}}_{t} *+\dot{\boldsymbol{e}}_{t}-\dot{\boldsymbol{p}}_{t}\right)\end{array}$} & -5.575 & 2.037 & -2.74 & 0.014 & \multirow{3}{*}{ - } & $\chi_{1}^{2}=0.60$ & \multirow{3}{*}{$\begin{array}{c}\chi^{2}{ }_{1}=0.521 \\
p \text {-value }=0.471\end{array}$} & \multirow{3}{*}{$\begin{array}{c}\chi^{2}{ }_{2}=0.93 \\
\text { p-value }=0.628\end{array}$} \\
\hline & 4.518 & 0.754 & 5.99 & $0.000 * * *$ & & p-value $=0.439$ & & \\
\hline & 0.191 & 0.445 & 0.43 & 0.673 & & & & \\
\hline
\end{tabular}

Notes to the tables:

Endogenous variables: $\dot{m}_{t}, \dot{c}_{t}, \imath \dot{n} v_{t}, \dot{x}_{t}, \dot{g}_{t}, \dot{y}_{t}, \dot{y}_{d, t}, \dot{r}_{t}$

Exogenous variables: $\left(\dot{p}_{t} *+\dot{e}_{t}-\dot{p}_{t}\right), \dot{y} *_{t}, t_{t}, i_{t}, i_{t}^{*}, p^{*}{ }_{t}, \dot{p}_{t-1,} \dot{c}_{t-1}, \dot{g}_{t-1}, \dot{x}_{t-1}, w_{D, t}$

$*, * *, * * *$ Coefficient significant at the $10 \%, 5 \%$ and $1 \%$ level, respectively 